\title{
CORRIGENDUM
}

\section{'WHERE WATER WELLS UP FROM THE EARTH': EXCAVATIONS AT THE FINDSPOT OF THE LATE BRONZE AGE HOARD FROM BROADWARD, SHROPSHIRE - CORRIGENDUM}

Richard Bradley, FSA, Jodie Lewis, David Mullin and Nicholas Branch, FSA

doi: https://doi.org/I0.I0I7/So003581515000I77, Published by Cambridge University Press 30 July 2015.

Figures I and 9 should be credited to Robbie Austrums. Figures 5 and 6 should be credited to Sarah Lambert-Gates based on originals by Robbie Austrums. Mr Austrums should also have received mention in the acknowledgments for the work he carried out on the survey data. The authors apologise for this oversight.

Fig I The location of the Broadward hoard. Drawing: Robbie Austrums

Fig 5 The microtopography of the areas studied, showing the location of the hoard and the position of the earthwork enclosure. Drawing: Sarah Lambert-Gates based on originals by Robbie Austrums

Fig 6 The area excavated around the findspot of the hoard. The shaded area shows the disturbed area around the former spring, and the symbol marks the position of the pit. Drawing: Sarah Lambert-Gates based on originals by Robbie Austrums

Fig 9 The topography of the circular enclosure, showing traces of ridge-and-furrow and the extent of excavation. Drawing: Robbie Austrums

\section{REFERENCE}

Bradley, R, Lewis, J, Mullin, D and Branch, N 2015. 'Where water wells up from the earth': Excavations at the findspot of the late
Bronze age hoard from broadward, Shropshire. The Antiquaries fournal, 95, 2I-64. doi: I0.IOI7/So00358I5I5000I77 